\title{
The profitability and production of a beef herd on transitional Cymbopogon- Themeda veld, receiving three different levels of lick supplementation - Preliminary results
}

\author{
L.A. Foster ${ }^{1}$, P.J. Fourie ${ }^{1 \#}$ \& F.W.C. Neser ${ }^{2}$ \\ ${ }^{1}$ Department of Agriculture, Central University of Technology, Free State, Private Bag X20539, Bloemfontein, 9300, \\ South Africa; ${ }^{2}$ Department of Animal, Wildlife and Grassland Sciences, University of the Free Sate, P.O.BOX 339, \\ Bloemfontein 9300, South Africa
}

(Received 4 January 2014; Accepted 5 June 2014; First published online 23 August 2014)

Copyright resides with the authors in terms of the Creative Commons Attribution 2.5 South African Licence.
See: http://creativecommons.org/licenses/by/2.5/za
Condition of use: The user may copy, distribute, transmit and adapt the work, but must recognise the authors and the South African
Journal of Animal Science.

\begin{abstract}
The importance of containing costs through the optimal utilization of feed emphasizes the need to optimize, rather than maximize, the rate of reproduction. It is, however, unknown which lick supplementation regimen, provided to an extensive beef herd on mixed veld, could bring about the most profitable and efficient farming enterprise. The aim of the study was thus to determine what lick supplementation regime would be most profitable in an extensive beef production system maintained on transitional CymbopogonThemeda veld. The different lick supplementation regimens offered differed in crude protein (CP) content, percentage non-degradable protein (NDP), metabolisable energy (ME) content, and recommended daily intake. $A$ herd of Drakensberger cows and heifers was divided into three treatment groups (Treatment $A$, Treatment $B$ and Treatment $C)$, with 70 animals $(n=70)$ per treatment group. The CP, NDP, ME content of the licks provided in Treatment A were higher than those provided in Treatment B and C, while the CP, NDP, ME content of the licks provided in Treatment $B$ were higher than those provided to Treatment $C$, but lower than those provided to Treatment A. The first two years' (2011 - 2012 and 2012 - 2013) preliminary results indicate no significant differences in parameters that affect cow herd performance (weaning weight, cow herd pregnancy rate, intercalving period) between treatments. However, substantial cost differences in the lick supplied between treatments was recorded; thus, affecting profitability. Significant differences between treatments in the pregnancy rates of the first-calf heifers was recorded in the second year, and indicated that providing protein in a drought during summer to first calf heifers may increase the calving rate and hence profitability.
\end{abstract}

Keywords: Beef cattle, cow herd production, extensive farming, lick supplementation, profitability

${ }^{\#}$ Corresponding author: pfourie@cut.ac.za

\section{Introduction}

Barely a day goes by without reference being made to the disadvantageous financial position of the South African farmer. Tougher economic conditions usually kindle a greater awareness in belt tightening and becoming more efficient, whether it be in the household or farm expenses (Lamb \& Maddock, 2009).

Farmers are then continually looking for means to increase production and profitability of their extensive livestock enterprises, often focusing on production measures and means to increase production, as production is the profit equation component directly affecting income from the enterprise. Farmers thus need to focus on cost management, another factor in the profit equation. Ultimately, the foremost focus is with profitability of the cow-calf enterprise (Ramsey et al., 2005). Lishman et al. (1984) indicated that it is by and large believed that reproduction rates in sheep and cattle reflect the level of management to which animals are exposed. The prime component of this management is believed to be the operating feeding conditions. The provision of feed to animals is the major cost input in almost any animal production system (Herd et al., 2003; Van der Westhuizen et al., 2004; Lamb \& Maddock, 2009). This has long been recognized by the pig and poultry industries, in which one can easily put a value to the cost of feed. Roughly $55 \%$ to $75 \%$ of the total costs related to beef cattle production are the feed costs (Arthur et al., 2001; Basarab et al., 2002). Although the cost of providing feed to extensive grazing cattle is more complex to quantify, it still remains a major input (Herd et al., 2003). 
Information on how to improve the production of an extensive weaning-calf production system under South African ranching conditions is readily available. It is generally achieved by primarily increasing the reproduction rate through an increased calving percentage, and also by increasing the average weaning weight of the calves. Feeding conditions influence the calving rate, but also have a direct effect on the profitability of the weaning-calf production system. Information on lick supplementation and lick formulations for cattle ranched in South Africa is readily available. There is, however, limited information available on the costs in providing these lick supplementations and their effect on the long term production and profitability of an entire beef cattle herd.

The proposed research was therefore an attempt to determine whether providing lick supplementations, which differ in crude protein content (CP), non-degradable-protein (NDP) content and metabolisable (ME) energy, to cattle during the same stage of production, grazing on CymbopogonThemeda veld, results in a difference in production performance and profitability.

\section{Materials and Methods}

The study was conducted on the farm "Quaggafontein" (30'46'S, 27022'E), situated south of Zastron in the south-eastern Free State, South Africa. The farm is located 1488 meters above sea level and the veld type is described by Acocks (1975) as transitional Cymbopogon-Themeda veld. The study site is situated in a temperate eastern plateau climatic zone, having cool wet summers and cold dry winters (Maree \& Casey, 1993). The rainfall varies between $400 \mathrm{~mm}$ and $600 \mathrm{~mm}$ per annum. The trial commenced on 1 August 2011 (winter) and will terminate on 31 July 2014.

Animal experimentation was conducted within the standard ethical norms, using a $3 \times 2$ factorial design. A herd of Drakensberger cows and heifers $(n=216)$, which were raised on the site preceding the study, was used. Pre-trial management of the animals was identical, and all the cows were pregnant and the calves weaned prior to the commencement of the study. The cows and heifers were then allocated to age groups, and thereafter randomly subdivided into Treatment A, B or C. Pregnant cows, pregnant heifers, 18-month-old heifers and weaning-calves were included in each of the three treatment groups.

All three treatment groups (A, B and C) were maintained on natural pasture and animals rotated between camps every two weeks in order to minimise a "camp effect" on the performance of the animals. Managerial skills pertaining to proper pasture and range management and supervision, in terms of reproduction, disease control and record keeping, was similar in all three groups. Lick supplementation was performed according to the production status of the animal, the treatment group to which the animal is allocated, as well as the season of the year. Wet season lick supplementation was designed to start on 1 November (late spring), but due to the early dry summer spells that had been experienced in 2011, 2012 and 2013, it was postponed to 1 December. Early dry season lick supplementation started on 1 April (autumn) and late dry season (winter) lick supplementation on 1 July. The composition of the licks that were provided during the early dry season and the late dry season were identical; however, adjustments were made in terms of the quantity provided. In the early dry season the animals were provided with only $80 \%$ of the maximum recommended daily intake of the lick.

The cow weight (W), coat score (CS) and body condition score (BCS) were determined on 15 March and again on 31 July. Pregnancy tests were performed at eight weeks following the breeding season. The following parameters were measured: inter-calving period of the cows, birth weight of the calves, 100 day and weaning weight (205 day weight) of the calves, weight of the cows at weaning, as well as the 12- month and 18-month body weight of the replacement heifers. Lick composition, lick intake, as well as the price of the licks supplied were monitored. The composition of the licks given during the late dry season to the pregnant cows and heifers and in the wet season to the cows with calves and first calf heifers are set out in Table 1.

The cow body weights, body condition scores and coat scores were recorded three times per year. The first yearly data collection event was on 1 August (late winter), the second on 15 March (autumn) and the third data collection event was on 31 July. All the cows were also weighed at weaning. During the first year (August 2011-July 2012) of the study, no significant $(P>0.05)$ differences in the mean body weight of the cows were recorded between treatments at the first and second ( 1 August and 15 March) data collection events. However, at weaning and at the last data collection events (31 July 2012), the cows in treatment $B$ were significantly heavier than those in treatment $\mathrm{A}$ or $\mathrm{C}$. No differences $(P>0.05)$ in the birth weight of the calves, 100-day weight or 205-day weight of the calves were recorded between treatments during the first year. The pregnancy rate and inter-calving period following the first year's breeding season, as well as the cost of the lick supplied per cow, is set in Table 2.

During the second year $(2012-2013)$ of the trial, there were also no differences $(P>0.05)$ recorded in the weight of the cows between treatments on 1 August, 15 March and 31 July. However, at weaning, the 
cows in treatment $A$ weighed significantly lighter than the cows in treatment $\mathrm{C}$. No significant differences in the birth weight or the 205-day weight of the calves were also recorded between treatments, but a significant difference $(P<0.0005)$ in the 100 -day weight of the calves was recorded, with the calves in treatment $A$ weighing more than those in treatments $\mathrm{B}$ and $\mathrm{C}$. The pregnancy rate and the inter-calving period following

Table 1 Composition of the different licks given to pregnant cows and heifers during the late dry season (late winter) and cows with calves and first calf heifers in the wet (summer) season

\begin{tabular}{|c|c|c|c|c|c|c|}
\hline & \multicolumn{6}{|c|}{ Late dry season lick supplementation (late winter) } \\
\hline & $\begin{array}{c}\text { Pregnant } \\
\text { cows A }\end{array}$ & $\begin{array}{c}\text { Pregnant } \\
\text { cows B }\end{array}$ & $\begin{array}{l}\text { Pregnant } \\
\text { cows C }\end{array}$ & $\begin{array}{l}\text { Pregnant } \\
\text { heifers A }\end{array}$ & $\begin{array}{l}\text { Pregnant } \\
\text { heifers B }\end{array}$ & $\begin{array}{l}\text { Pregnant } \\
\text { heifers C }\end{array}$ \\
\hline Crude protein (\%) & 36.7 & 46.6 & 47.5 & 30.6 & 32.9 & 47.5 \\
\hline NPN (\%) & 77.5 & 88.7 & 93 & 47.4 & 72.4 & 93 \\
\hline $\mathrm{ME}(\mathrm{MJ} / \mathrm{kg})$ & 5.25 & 4.4 & 2.4 & 7.4 & 6.9 & 2.4 \\
\hline Calcium (\%) & 2.7 & 3.7 & 3.84 & 1.9 & 2.2 & 3.84 \\
\hline Phosphorus (\%) & 1.4 & 1.9 & 1.97 & 1.3 & 1.25 & 1.97 \\
\hline \multirow[t]{3}{*}{$\begin{array}{l}\text { Daily intake } \\
\text { (g/animal/day) }\end{array}$} & $450-650$ & $300-500$ & $350-500$ & $1000-2000$ & $600-700$ & $350-500$ \\
\hline & \multicolumn{6}{|c|}{ Wet season lick supplementation (summer) } \\
\hline & $\begin{array}{c}\text { Cows with } \\
\text { calves A }\end{array}$ & $\begin{array}{l}\text { Cows with } \\
\text { calves B }\end{array}$ & $\begin{array}{l}\text { Cows with } \\
\text { calves C }\end{array}$ & $\begin{array}{c}1^{\text {st }} \text { Calf } \\
\text { heifers A }\end{array}$ & $\begin{array}{c}1^{\text {st }} \text { Calf } \\
\text { heifers B }\end{array}$ & $\begin{array}{c}1^{\text {st }} \text { Calf } \\
\text { heifers C }\end{array}$ \\
\hline Crude protein (\%) & 15 & 0 & 0 & 16.4 & 15 & 0 \\
\hline NPN (\%) & 90.7 & 0 & 0 & 37.0 & 90.7 & 0 \\
\hline $\mathrm{ME}(\mathrm{MJ} / \mathrm{kg})$ & 0 & 0 & 0 & 9.0 & 0 & 0 \\
\hline Calcium (\%) & 5.0 & 11.8 & 11.8 & 2.1 & 5.0 & 11.8 \\
\hline Phosphorus (\%) & 8.0 & 6.0 & 6.0 & 1.3 & 8.0 & 6.0 \\
\hline $\begin{array}{l}\text { Daily intake } \\
\text { (g/animal/day) }\end{array}$ & $120-240$ & $100-240$ & $100-240$ & $1000-1500$ & $120-240$ & $100-240$ \\
\hline
\end{tabular}

NPN: non-protein nitrogen; ME: metabolisable energy.

Table 2 Mean ( \pm SD) birth weight $(\mathrm{kg}), 100$-day and 205-day weight $(\mathrm{kg})$ of cows' calves, weight of cows $(\mathrm{kg})$ at weaning, ICP (days), conception rate (\%) and price of lick per treatment following different lick supplementations

\begin{tabular}{lccccccc}
\hline Treatment group & $\begin{array}{c}\text { Calf birth } \\
\text { weight } \\
(\mathbf{k g})\end{array}$ & $\begin{array}{c}\text { 100-day } \\
\text { calf weight } \\
\mathbf{( k g )}\end{array}$ & $\begin{array}{c}\text { 205-day } \\
\text { calf weight } \\
\mathbf{( k g )}\end{array}$ & $\begin{array}{c}\text { Cow weight } \\
\text { at weaning } \\
(\mathbf{k g})\end{array}$ & $\begin{array}{c}\text { ICP } \\
\text { (days) }\end{array}$ & $\begin{array}{c}\text { Conception } \\
\text { rate (\%) }\end{array}$ & $\begin{array}{c}\text { Price of lick } \\
\text { per cow }\end{array}$ \\
\hline & & \multicolumn{1}{c}{ 1 August 2011 -31 July 2012} \\
Cows treatment A & $39.5^{\mathrm{a}} \pm 4.9$ & $136^{\mathrm{a}} \pm 21.6$ & $223^{\mathrm{a}} \pm 26.0$ & $535^{\mathrm{a}} \pm 52.3$ & 380 & 90 & $\mathrm{R} 477.29$ \\
Cows treatment B & $39.2^{\mathrm{a}} \pm 3.9$ & $133^{\mathrm{a}} \pm 16.9$ & $220^{\mathrm{a}} \pm 28.0$ & $562^{\mathrm{b}} \pm 55.8$ & 377 & 91 & $\mathrm{R} 319.52$ \\
Cows treatment C & $37.9^{\mathrm{a}} \pm 3.9$ & $130^{\mathrm{a}} \pm 16.4$ & $214^{\mathrm{a}} \pm 23.2$ & $529^{\mathrm{a}} \pm 57.4$ & 382 & 92 & $\mathrm{R} 274.25$ \\
\hline
\end{tabular}

1 August 2012 - 31 July 2013

\begin{tabular}{llllllll}
\hline Cows treatment A & $39.3^{\mathrm{a}} \pm 4.7$ & $147^{\mathrm{a}} \pm 16.9$ & $218^{\mathrm{a}} \pm 24.3$ & $540^{\mathrm{a}} \pm 57.8$ & 397 & 91 & $\mathrm{R} 558.91$ \\
Cows treatment B & $38.0^{\mathrm{a}} \pm 4.7$ & $133^{\mathrm{b}} \pm 18.4$ & $211^{\mathrm{a}} \pm 25.6$ & $551^{\mathrm{ab}} \pm 52.1$ & 385 & 88 & $\mathrm{R} 422.33$ \\
Cows treatment C & $37.4^{\mathrm{a}} \pm 4.9$ & $131^{\mathrm{b}} \pm 17.9$ & $210^{\mathrm{a}} \pm 26.5$ & $563^{\mathrm{b}} \pm 53.0$ & 398 & 94 & $\mathrm{R} 326.36$
\end{tabular}

${ }^{1}$ Means in columns with different superscripts differ significantly $(P<0.05)$. ICP: intercalving period. 
the second year's breeding season, as well as the cost of the lick supplied per cow, are set out in Table 2 .

The same procedures were followed for the first-calf heifers as for the cows. During the first year (2011 - 2012) of the trial no significant differences in the body weight of the first-calf heifers, birth weight of the calves, 100-day weight or 205-day weight of the calves, as well as the weight of the first-calf heifers at weaning, were recorded between treatments. The pregnancy rate and inter-calving period following the first year's breeding season, as well as the cost of the lick supplied per first-calf heifer, is set out in Table 3.

During the second year $(2012$ - 2013) of the trial, a difference $(P<0.05)$ in the body weight of the firstcalf heifers was recorded at the second data collection event (15 March 2013), with the first-calf heifers in treatment $B$ weighing less than those in treatment $A$. No significant difference in the birth weight or 205-day weight of the calves was recorded between treatments. However, a significant difference $(P<0.05)$ in the 100-day weight of the calves was recorded, with the calves in treatment $B$, weighing more than those in treatment $C$. A significant difference $(P<0.05)$ in the weight of the first-calf heifers at weaning was recorded with first-calf heifers in treatment B weighing less at weaning than those in treatment A or C. The pregnancy rate following the first year's breeding season, as well as the cost of the lick supplied per first-calf heifer, is set out in Table 3.

Table 3 Mean ( \pm SD) birth weight $(\mathrm{kg}), 100$-day and 205-day weight of the first-calf heifers' calves $(\mathrm{kg})$, weight of first calf heifers $(\mathrm{kg})$ at weaning, ICP (days), conception rate (\%) and price of lick per treatment following different lick supplementations

\begin{tabular}{|c|c|c|c|c|c|c|}
\hline Treatment group & $\begin{array}{l}\text { Calf birth } \\
\text { weight (kg) }\end{array}$ & $\begin{array}{l}\text { 100-day calf } \\
\text { weight }(\mathrm{kg})\end{array}$ & $\begin{array}{l}\text { 205-day calf } \\
\text { weight }(\mathrm{kg})\end{array}$ & $\begin{array}{c}1^{\text {st }} \text { calf heifer } \\
\text { weight at } \\
\text { weaning }(\mathrm{kg})\end{array}$ & $\begin{array}{l}\text { Conception } \\
\text { rate }(\%)\end{array}$ & $\begin{array}{c}\text { Price of lick } \\
\text { per cow }\end{array}$ \\
\hline \multicolumn{7}{|c|}{1 August 2012 - 31 July 2013} \\
\hline $1^{\text {st }}$ Calf heifers $A$ & $37.6^{\mathrm{a}} \pm 3.3$ & $146^{\mathrm{a}} \pm 15.7$ & $258^{\mathrm{a}} \pm 21.4$ & $527^{a} \pm 42.6$ & 100 & R711.92 \\
\hline $1^{\text {st }}$ Calf heifers $B$ & $36.3^{\mathrm{a}} \pm 2.7$ & $133^{a} \pm 19.2$ & $233^{a} \pm 26.4$ & $505^{\mathrm{a}} \pm 42.0$ & 100 & R382.92 \\
\hline $1^{\text {st }}$ Calf heifers $\mathrm{C}$ & $39.0^{\mathrm{a}} \pm 4.7$ & $141^{\mathrm{a}} \pm 13.2$ & $243^{a} \pm 23.1$ & $509^{a} \pm 40.9$ & 100 & $\mathrm{R} 240.12$ \\
\hline \multicolumn{7}{|c|}{1 August 2012 - 31 July 2013} \\
\hline $1^{\text {st }}$ Calf heifers $A$ & $39.3^{\mathrm{a}} \pm 3.9$ & $133^{\mathrm{ab}} \pm 15.0$ & $218^{a} \pm 21.4$ & $496^{a} \pm 30.5$ & 91 & R1 100.44 \\
\hline $1^{\text {st }}$ Calf heifers $B$ & $36.1^{\mathrm{a}} \pm 4.6$ & $144^{\mathrm{b}} \pm 7.9$ & $218^{a} \pm 12.1$ & $454^{b} \pm 41.5$ & 100 & $\mathrm{R} 507.98$ \\
\hline $1^{\text {st }}$ Calf heifers $C$ & $40.5^{a} \pm 3.2$ & $131^{\mathrm{a}} \pm 13.5$ & $206^{\mathrm{a}} \pm 26.5$ & $481^{\mathrm{a}} \pm 41.8$ & 67 & R266.84 \\
\hline
\end{tabular}

${ }^{1}$ Means in columns with different superscripts differ significantly $P<0.05$. ICP: inter calving period.

Table 4 The average net income per treatment group, calculated using average weaning weight, price per $\mathrm{kg}$ live weight, calving percentage and the cost of lick supplementation

\begin{tabular}{ccccccc}
\hline & $\begin{array}{c}\text { Avg. weaning } \\
\text { weight } \\
(\mathbf{2 0 1 1 - 2 0 1 3 )}\end{array}$ & $\begin{array}{c}\text { Price per kg } \\
\text { (live weight) } \\
\text { (R/kg) }\end{array}$ & $\begin{array}{c}\text { Avg. calving } \\
\text { \% } \\
(\mathbf{2 0 1 1 - 2 0 1 3 )}\end{array}$ & $\begin{array}{c}\text { Gross income } \\
\text { (a x b x c) }\end{array}$ & $\begin{array}{c}\text { Avg. lick } \\
\text { cost per } \\
\mathbf{1 0 0} \text { animals } \\
(\mathbf{2 0 1 1 - 2 0 1 3 )}\end{array}$ & $\begin{array}{c}\text { Net income } \\
\text { (d - e) }\end{array}$ \\
\hline & $\mathrm{a}$ & $\mathrm{b}$ & $\mathrm{c}$ & $\mathrm{d}$ & $\mathrm{e}$ & $\mathrm{f}$ \\
\hline Cow treatment A & $220.5 \mathrm{~kg}$ & $\mathrm{R} 16.50$ & 90.5 & $\mathrm{R} 329262.00$ & $\mathrm{R} 51810.00$ & $\mathrm{R} 277452.00$ \\
Cow treatment B & $215.5 \mathrm{~kg}$ & $\mathrm{R} 16.50$ & 89.5 & $\mathrm{R} 318240.00$ & $\mathrm{R} 37093.00$ & $\mathrm{R} 281147.00$ \\
Cow treatment C & $212 \mathrm{~kg}$ & $\mathrm{R} 16.50$ & 93 & $\mathrm{R} 325314.00$ & $\mathrm{R} 30032.00$ & $\mathrm{R} 295282.00$ \\
\hline $1^{\text {st }}$ Calf heifers A & $238 \mathrm{~kg}$ & $\mathrm{R} 16.50$ & 95.5 & $\mathrm{R} 375029.00$ & $\mathrm{R} 90618.00$ & $\mathrm{R} 284411.00$ \\
$1^{\text {st }}$ Calf heifers B & $225.5 \mathrm{~kg}$ & $\mathrm{R} 16.50$ & 100 & $\mathrm{R} 372075.00$ & $\mathrm{R} 44545.00$ & $\mathrm{R} 327530.00$ \\
$1^{\text {st }}$ Calf heifers C & $224.5 \mathrm{~kg}$ & $\mathrm{R} 16.50$ & 83.5 & $\mathrm{R} 309305.00$ & $\mathrm{R} 25348.00$ & $\mathrm{R} 283957.00$ \\
\hline
\end{tabular}


The profitability of the cow-calf enterprise within a particular year is impacted by a number of factors. An analysis of the most basic farm records can quantify imperative issues affecting herd success (e.g. reproductive performance, calf growth and weaning weight, market prices and herd turnover rate). To encapsulate the entire picture regarding profit, these performance parameters must be integrated with the cost of production. Time and again data reveals that large differences exist between herds in feed and operating costs. This variation in expenditure, coupled with differences in production parameters, equate to substantial differences in profitability (Greiner, 2010).

\section{Conclusion}

Generally, farmers focus on production parameters and the means to increase production. However, as the profitability of a beef production system depends on both inputs and outputs, farmers also need to focus on cost management. Two years of preliminary results in this study indicate no significant differences between treatments in the production parameters of the cows, but differences in the cost of lick supplementation between treatments. Even though the calves in treatment $C$ were lighter at weaning than the calves in treatment $A$ and $B$, the cattle in treatment $C$ were more profitable due to a higher calving rate and a lower expenditure on lick supplementation.

Relatively "normal" summer grazing conditions were experienced during the first year of the trial and the preliminary results of the trial indicate that when a "normal" summer is experienced (during the calving and mating season) of a three-year-old first-calf heifer, a salt and phosphate lick would suffice and bring about the most profit, compared to when a protein and energy are included in the summer lick.

Extremely adverse grazing conditions were experienced during the second year of the trial, as a severe drought was experienced. It is believed that these adverse conditions were the cause of the significantly lower conception rate $(67 \%)$ of the first-calf heifers in treatment $\mathrm{C}$, compared to the first-calf heifers in treatments A and B. It would thus appear that during a dry summer there is merit in including protein in a lick being supplied to the three year old first-calf heifers during the breeding season. However, adding energy and NPN makes the lick supplementation expensive, which has a negative effect on the profitability of the weaner-calf production system (Table 4).

\section{Acknowledgements}

The authors would like to acknowledge the SoAR Scholarship programme of the CUT, Free State for financial assistance towards the study.

\section{References}

Acocks, J.P.H., 1975. Veld types of South Africa. Mem. Botanical Survey of South Africa. pp. 57.

Arthur, P.F., Renand, G. \& Krauss, D., 2001. Genetic and phenotypic relationships among different measures of growth and feed efficiency in young Charolais bulls. Livest. Prod. Sci. 68,131-139.

Basarab, J.A., Price, M.A. \& Okine, E.K., 2002. Commercialisation of net feed efficiency. Memo. Western Forage group, Alberta Agricultural Food and Rural Development Centre. Lacombe, Alberta, Canada. p. 12.

Herd, R.M., Archer, J.A. \& Arthur, P.F., 2003. Reducing the cost of beef production through genetic improvement in residual feed intake: Opportunity and challenges to application. J. Anim. Sci. 81 (E. Suppl. 1), E9-E17.

Greiner, S.P., 2010. Cow herd performance and profitability: Measuring how you stack up [Online]Available:,URL: http://pubs.ext.vt.edu/news/livestock/2010/04/LU_04-01-10-3.html

Maree, C. \& Casey, N.H., 1993. Livestock Production Systems. Agri Development Foundation, Brooklyn, South Africa.

Lamb, G.C. \& Maddock, T., 2009. Feed efficiency in cows. Cash, Cows and Calves. Florida Beef Cattle Short Course.

Lishman, A.W., Paterson, A.G. \& Beghin, S.M., 1984. Reproduction rate as a factor in meat production. S. Afr. J. Anim. Sci., 14, 164-168.

Ramsey, R., Doye, D., Ward, C., Mcgrann, J., Falconer, L. \& Bevers, S., 2005. Factors affecting beef cowherd costs, production, and profits. J. Agric. Appl. Econ. 37 (1), 91-99.

Van der Westhuizen, R.R., Van der Westhuizen, J. \& Schoeman, S.J., 2004. Genetic relationship between feed efficiency and profitability traits in beef cattle. S. Afr. J. Anim. Sci. 34, 50-53. 